\title{
Task-based language teaching to improve students' speaking achievement
}

\author{
Nurulina Hakim $^{1^{*}}$, Mahpul ${ }^{2}$, Fajar Riyantika ${ }^{3}$ \\ Universitas Lampung, Jl. Prof. Dr. SumantriBrojonegoro, Rajabasa, Bandar Lampung ${ }^{1,2,3}$ \\ *hakimnurulina@gmail.com
}

\begin{abstract}
The objectives of this research were to investigate a significant improvement in students' speaking achievement in term of complexity, accuracy and fluency aspect after the implementation of TBLT approach. The topic of the material that this research took was Narrative text in an online class. This research was conducted at the tenth grade of SMA Global Madani, Bandar Lampung. Class 10 Science 2 consisted of 15 students was chosen as the sample of this research by random sampling. The design used was the one group pre-test posttest.Speaking test was the instrument to measure the pre-test and post-test. The mean of pre-test (58) showed an increase in post-test $(64)$. The results of the t-value $(8,235)$ is higher than the ttable score (2.1315) with the significant of two tailed 0,000 lower than 0.05 . This means $\mathrm{H}_{1}$ is accepted.
\end{abstract}

\section{Keywords: TBLT, Speaking, Narrative Text in Speaking}

\section{INTRODUCTION}

Speaking is the most challenging aspect of learning a target language because we cannot pull off what has been said, (Nunan, 2003). The use of inappropriate teaching methods can lead students not to get the goal of mastering the target language. Many teachers use conventional methods that do not encourage students to speak English in class. A conventional method implemented in the speaking class has been likely uninteresting and does not motivate them to speak English (Mudra, 2016). They were uninterested because the method is not suitable to use in the classroom activity. The topic does not relate to the students' real-life activity. They need a realworld task that can help them to improve their speaking ability. Therefore, a task is necessary to trigger them to improve their speaking ability.

Willis (1996) defines a task as an activity where the learner uses the target language for a communicative purpose to achieve an outcome or development.Therefore, the implementation of TBLT effectively improved the students' speaking achievement. In this research, the researcher was interested in doing further research, but it was still merely focused on task-based language teaching in speaking.

The speaking performance measurement was complexity, accuracy, and fluency aspect. However, the focus of each aspect was divided into syntactic complexity, lexis accuracy, and speech rate. Therefore, here is the explanation:

a. Complexity

According to Skehan (1996), complexity is the elaboration or ambition of the produced language. Moreover, Ellis (2003) states that the extent to which the language is made in performing an elaborated and varied task is called complexity. Complexity refers to the capacity 
to use vocabulary that is more advanced. with the possibility that it may not control such language so effectively. This may also involve a greater willingness to take risks and use fewer controlled language subsystems. This area correlates with a greater likelihood of restricting, that is, change and development in the interlanguage system. Ellis and Barkhuizen (2005) categorize the types of complexity measures according to the measurement object into interactional, propositional, functional, grammatical, and lexical. Thus, for the presence of this research, the researcher took Syntactic complexity by counting the frequency of subordinate and coordinate used in a sentence.

\section{b. Accuracy}

According to Ellis (2003), accuracy refers to how the language produced in performing a task conforms to target language norms. The aspects observed in accuracy focus on particular error types, such as correct verb forms, the proportion of correct-past-tense use, and article use. Ragini (2019) divides lexical into three aspects, lexical accuracy, semantic accuracy, and grammatical accuracy. However, the researcher could only assess the students' sentences by analyzing the lexical accuracy. Lexical accuracy refers to using words appropriately and correctly in communication.

\section{c. Fluency}

Ellis (2003), fluency refers to the extent to which the language produced in performing a task manifests pausing, hesitation, or reformulation. Fillmore (1979) also defined fluency as the ability to talk in coherent, reasoned, and semantically dense sentences, have appropriate things to say in a wide range of contexts and be creative and imaginative in language use. Besides, Kormos and Denes (2004) proposed the variable of speaking fluency such as speech rate, articulation rate, phonation-time ratio, mean length of runs, total number of silent pauses per minute, mean length of silent pauses, total number of filled pauses per minute, total number of disfluencies per minutes. Based on the definition above, the researcher believed that assessing the students' length for more lexical spoken or what is called speech rate would fit the sample of this research rather than measure their pauses, reformulation, or hesitation. Therefore, the speech rate counting has been taken for this measurement by taking the Kormos and Denes' (2004) framework, the researcher measured speech and articulation rates in terms of syllables per minute not pruned syllables. Therefore, the speech given would be count in seconds, including the pauses time, then multiplied by sixty.

In brief, these components of speaking above are essential for the learners to master English for better communication in the target language. In addition, these became the measurement of this research. As pointed above, the measurement aspects are syntactic complexity, lexical accuracy, and speech rate.

Regarding the background and explanation above, the problem was formulated into following research question: Is there any significant improvement on the students' speaking achievement in terms of complexity, accuracy, and fluency aspect after the implementation of Task Based Language Teaching? Meanwhile, the objective of the research was to find out if there is any significant improvement in speaking achievement in terms of complexity, accuracy, and fluency aspect after being taught by TBLT. 
The result of this research would be helpful for the further researcher and as the reference for the English teachers who want to use TBLT approach. The scope of this research was taking a part of the use of TBLT in EFL classroom by concerning to Ellis in 2003. The TBLT type of task that the researcher chose was Meaning-focused task activity with its three types of activities (information-gap, reasoning-gap, and opinion-gap). She chose pictures for the pre and post activity as the media to trigger students' speaking achievement, recorded their speaking conversation, and transcribed it to analyze the speaking performance aspects, syntactic complexity, lexical accuracy, and speech rate for fluency.

\section{METHODS}

This research was aimed to find the effect of Task Based Language Teaching technique. In order to find out the result, the researcher used a quantitative method as a research design.The design of this research is the one group pre-test post-test design. The researcher used a pre-test, treatments, and a post-test. The design is $\mathrm{T}_{1} \mathrm{X} \mathrm{T}_{2}$

Notes:

$\mathrm{T}_{1}$ : refers to pre test

$\mathrm{X}$ : refers to treatments (teaching speaking using TBLT)

$\mathrm{T}_{2}$ : refers to post test

The treatment conducted in three meetings and the time allocation provided was $2 \times 45$ minutes each meeting.

\section{Participants}

The population of this research was the tenth grade students of Senior High School of Global Madani in the academic year of 2020/2021. The class Ten Science Two (X IPA 2) was chosen by random sampling. There were 15 students in the class and the chosen class represented the population of the school for being the sample of this research.

\section{Instrument}

To figure out whether the objective of the research had achieved or not, the researcher used research instrument. The instrument of this research was speaking test. There were pre-test and post-test. First, the pre-test was given before the treatments to see the students' achievement in speaking. Then, the post-test was given to the students after the treatments. It aimed to see the treatment's effect on the students' achievement in speaking after Task-Based Language Teaching conducted in their learning.

\section{Data analysis}

The research questions' data were analyzed after gaining the pre-test and the post-test results. It aimed to see whether the Task-Based Language Teaching technique has an effect to the students' speaking achievement or not. To analyze the data of the students' mean score in the pre-test and the post-test in each aspect, the researcher calculated them by using Paired Sample T-Test in SPSSS version 20. Here are the complete steps in order to get the result of this research:

1. Transcribing the students' utterances 
The researcher transcribed the students' utterance of pretest and posttest from their recording.

2. Scoring the pre-test and post-test

The researcher scored the students' speaking performance of the test. Then the researcher counted the average score, which would be taken as the final score.

3. Tabulating the test result and finding the mean of the data

The researcher calculated the data (the pre-test and the post-test) in order to see the mean of the test. The result will be analyzed using Paired Simple T-Test using SPSS program. Then, the researcher compared both the pre-test and the post-test to see whether there was an improvement or not.

4. Drawing conclusion

By comparing the means of the pre-test and post-test, the result used to test the researcher's hypothesis.

\section{RESULTS AND DISCUSSION}

\section{Results}

The pre-test and the post-test were administered to determine a significant improvement in students' speaking achievement after TBLT implemented in the class. Below is the distribution of the students' speaking score in the pre-test. The lowest score was 43 with the frequency of 1 person so does the highest with the score of 74 .

Table 1. Distribution Frequency of Students' Pre-test

\begin{tabular}{rrrrrr}
\hline & \multicolumn{2}{c}{ Pre-test } & \\
\hline & Frequency & Percent & Valid Percent & $\begin{array}{c}\text { Cumulative } \\
\text { Percent }\end{array}$ \\
\hline 43.00 & 1 & 6.7 & 6.7 & 6.7 \\
48.00 & 1 & 6.7 & 6.7 & 13.3 \\
52.00 & 1 & 6.7 & 6.7 & 20.0 \\
54.00 & 2 & 13.3 & 13.3 & 33.3 \\
56.00 & 1 & 6.7 & 6.7 & 40.0 \\
Valid & 2 & 13.3 & 13.3 & 53.3 \\
57.00 & 2 & 13.3 & 13.3 & 66.7 \\
61.00 & 1 & 6.7 & 6.7 & 73.3 \\
62.00 & 2 & 13.3 & 13.3 & 86.7 \\
64.00 & 1 & 6.7 & 6.7 & 93.3 \\
72.00 & 1 & 6.7 & 6.7 & 100.0 \\
74.00 & 15 & 100.0 & 100.0 & \\
\hline
\end{tabular}

Meanwhile, the post-test was administered to determine whether there was a significant improvement of the students' speaking ability or not after giving three treatments. The students were asked to tell the two different narrative stories from the pre-test and did it live through Zoom meeting. The post-test mean score was 64, with the highest score was 77 and the lowest score was 51. Below is the frequency of students' post-test: 
Table 2 Distribution Frequency of Students' Post-test

Post-test

\begin{tabular}{rrrrrr}
\hline & Frequency & Percent & Valid Percent & \multicolumn{2}{c}{$\begin{array}{c}\text { Cumulative } \\
\text { Percent }\end{array}$} \\
\hline 51.00 & 1 & 6.7 & 6.7 & 6.7 \\
& 57.00 & 1 & 6.7 & 6.7 & 13.3 \\
& 59.00 & 1 & 6.7 & 6.7 & 20.0 \\
& 61.00 & 3 & 20.0 & 20.0 & 40.0 \\
& 63.00 & 1 & 6.7 & 13.3 & 53.3 \\
& 65.00 & 2 & 13.3 & 6.7 & 60.0 \\
& 68.00 & 1 & 6.7 & 6.7 & 73.3 \\
& 71.00 & 1 & 6.7 & 6.7 & 80.0 \\
& 74.00 & 1 & 6.7 & 6.7 & 96.7 \\
& 77.00 & 1 & 6.7 & 6.7 & 100.0 \\
& 87.00 & 15 & 100.0 & 100.0 & \\
\hline
\end{tabular}

After that, there is also the table comparison of students' pre-test and post-test score but in each aspect of speaking performance, which are complexity, accuracy, and fluency, as illustrated below:

Table 4.3 Result of Aspects Speaking Measurement

\begin{tabular}{lrrr}
\hline \multicolumn{1}{r}{ Aspects } & Mean of Pre-test & $\begin{array}{r}\text { Mean of Post- } \\
\text { test }\end{array}$ & Increase \\
\hline Complexity & 6.191 & 8.046 & 1.855 \\
\hline Accuracy & 7 & 5.771 & 1.33 \\
\hline Fluency & 163.481 & 180.818 & 17.33 \\
\hline Total & $\mathbf{1 7 6 . 7 8 3}$ & $\mathbf{1 9 4 . 6 3 6}$ & $\mathbf{2 0 . 5 2 9}$ \\
\hline
\end{tabular}

It could be seen that the highest aspect to improve is fluency while the lowest is accuracy.

\section{Discussion}

The researcher conducted this research in SMA Global Madani, and X IPA 2 was chosen as the representative using random sampling. The class consisted of 15 students who had done the pretest, treatments, and the post-test. 
The students were asked to describe and compare two different narrative texts in the pre-test and post-test. The students submitted the pre-test video through Google Drive, while the post-test was conducted through Zoom Meeting. Furthermore, the treatments were conducted online through Zoom Meeting, and those were divided into three meetings. The first meeting focused on describing the character of the narrative text. The second meeting focused on comparing the two different narrative texts. The last meeting focused on both of the tasks.

To find out the objective of this research, the researcher used one instrument; a speaking test. The results had answered the objective explained above; there was a significant improvement in the students' speaking achievement in terms of complexity, accuracy, and fluency aspect after the implementation of Task-Based Language Teaching by comparing the mean of the pre-test (58), and the post-test (64) with an increase is 6 points.

Moreover, the highest increase from the three aspects is fluency (17), and the lowest is accuracy (1.3). The reason behind this was that to measure fluency, the researcher had to count the syllables and times to 60 seconds, while measuring complexity and accuracy, the researcher had to count it in percent (\%). However, this finding is in line with the theory from Skehan (1999) that TBLT in speaking performance with the topic of narrative retelling improves the most in fluency and complexity aspects but lack in accuracy. Besides, the TBLT type that the researcher used was Meaning-Focused activity, which was not focused on the language form (accuracy), but still, there was an improvement in the accuracy aspect. Therefore, the total increase of all aspects is 20.5 .

After obtaining the data, the researcher found that TBLT does improve the students speaking not only by the three aspects stated above. During the pre-test, they were good because it was a video submission, but when the first meeting took place; their speaking was proven worse than the pre-test. More than the half of them were shy and did not have any idea how to start the speaking. Thus, for the times given, there were dozens of pauses in total that they made because they were unsure how to deliver their ideas. After the three meetings

In conclusion, based on the results of the findings, the researcher found the implementation of TBLT could improve the students speaking achievement, just like with the previous findings from Anggraini (2019) andIswari (2015). However, all previous researches were done offline. Therefore, this research met some difficulties during its process. Some of those were: unable to see the students and interact directly due to online meeting, connection problem, and the offer to change the process of the post-test to Zoom Live from video submission.

\section{CONCLUSION AND SUGGESTIONS}

\section{Conclusion}

TBLT approach gave significant improvement towards students' speaking achievement. It can be seen by comparing the mean of students' pre-test and post-test based on the total score of complexity, accuracy, and fluency aspect (20.5). The highest increased aspect is fluency (17.3) and the lowest is accuracy (1.3). The significant improvement is also supported by the result of the Paired Sample T-Test where the p-value (0.000) is lower than alpha (0.05), which means the $\mathrm{H}_{1}$ is accepted.This research has been finished in an online situation by using the media that all students were able to attend (Zoom Meeting). In addition, the narrative topics were related to the three speaking performance aspects that are complexity, accuracy, and fluency. 


\section{Suggestion for English Teachers}

English teacher who usually uses a conventional method in speaking practice in which most of the students memorize the explanation should try to use TBLT approach to improve the students' speaking achievement.During the treatments, the researcher found that some students were active and had fun in the break out rooms. This could be a suggestion for the English teacher to let them discuss freely about the task but still manage their action. The researcher is aware that the learning time decreased due to online. Therefore, the teacher should split the material with the specific objective for each meeting and make them improve gradually.

\section{Suggestion for further researcher}

Regarding the researcher experience, it is better for further researcher to conduct the research of TBLT not in the virtual application, unless everything involved (students, time management, and school's principle) could cooperate during the whole occasion. The further researcher might focus on the use of subordinate in order to gain a higher achievement of syntactic complexity since only a few students from this research applied it.For the further researcher, checking their response could be applied in this research to see their opinions toward the implementation of TBLT in their class activity.

\section{REFERENCES}

Anggraini, K. (2019). Teaching speaking through task based language teaching at the first grade students of SMAN 1 GedongTataan. Lampung University.

Ellis, R. (2003). Task-based language learning and teaching. Oxford: Oxford University Press.

Ellis R. and G. Barkhuizen. (2005). Analysing learner language. Oxford: Oxford University Press

Fillmore, L W (1979) Individual differences in second language acquisition, in Fillmore, C, Kempler, D and Wang, W Y S (Eds) Individual Differences in Language Ability and Language Behavior, New York: Academic Press.

Iswari, D. (2015). The effect of task based language teaching on students' speaking achievement. University of Lampung. Bandar Lampung.

Kormos, J. \&Dénes, M. (2004). Exploring measures and perceptions of fluency in the speech of second language learners. An International Journal of Educational Technology and Applied Linguistics. EötvösLoránd University, Budapest System (32)

Mudra, H. (2016). Enhancing students' speaking skill through task based language teaching at English tadris department of STAIN Kerinci.JournalTarbiyahIAIN.

Nunan, D. (2003). Practical English language teaching. Newyork: McGraw-Hill.

Ragini, S. (2019) Developing lexical accuracy in communication using webtools. College of Engineering \& Technology Kandlakoya, Medchal Road Hyderabad - 501401

Skehan\& Foster. (1999). Theinfluence of task structure and processing conditions on narrative retellings. Thames Valley University.

Willis, J. (1996). A framework for task-based learning. Longman. 